\title{
PENERAPAN PEMBELAJARAN GROUP INVESTIGATION BERBANTUAN MEDIA AUDIO VISUAL UNTUK MENINGKATKAN HASIL BELAJAR IPS
}

\author{
Ni Kdk Tariani ${ }^{1}$, Md Sumantri ${ }^{2}$ \\ 1,2Jurusan Pendidikan Guru Sekolah Dasar, FIP \\ Universitas Pendidikan Ganesha \\ Singaraja, Indonesia
}

e-mail: nikadektariani@gmail.com ${ }^{1}$, madesumantri_pgsd@yahoo.co.id ${ }^{2}$

\begin{abstract}
Abstrak
Penelitian ini bertujuan untuk mengetahui hasil belajar IPS setelah diterapkan model pembelajaran kooperatif tipe Group Investigation (GI) berbantuan media audio visual pada siswa kelas V SD Negeri 1 Banjar Jawa Tahun Pelajaran 2017/2018. Penelitian ini merupakan jenis penelitian tindakan kelas yang dilaksanakan dalam dua siklus dan pada setiap siklus terdiri dari 4 tahapan yaitu perencanaan, tindakan, observasi/evaluasi, dan refleksi. Setiap siklus dilaksanakan dalam 3 kali pertemuan yang terdiri dari 2 kali pertemuan untuk membelajarkan materi, 1 kali pertemuan untuk melaksanakan evaluasi. Subjek penelitian yaitu siswa kelas V SD Negeri 1 Banjar Jawa Tahun Pelajaran 2017/2018 sebanyak 39 orang yaitu 19 orang putra dan 20 orang putri. Objek penelitian ini yaitu hasil belajar IPS. Observer dalam penelitian ini yaitu guru kelas $V$ dan rekan mahasiswa PPL SD Negeri 1 Banjar Jawa. Metode pengumpulan data pada penelitian ini yaitu menggunakan metode tes dan nontes. Metode tes digunakan untuk penilaian pengetahuan, sedangkan metode nontes digunakan untuk penilaian sikap dan keterampilan. Instrumen pengumpulan data yang digunakan pada penelitian ini yaitu lembar soal obyektif, lembar observasi penilaian sikap, dan lembar observasi penilaian keterampilan siswa. Data yang telah berhasil dikumpulkan, dianalisis menggunakan metode analisis statistik deskriptif dan analisis deskriptif kuantitatif. Persentase hasil belajar pada siklus I sebesar $73 \%$, sedangkan pada siklus II sebesar $87 \%$, dan terjadi peningkatan sebesar 0,51 . Berdasarkan hasil tersebut dapat disimpulkan bahwa penerapan model pembelajaran kooperatif tipe group investigation (GI) dapat meningkatkan hasil belajar IPS pada siswa kelas V SD Negeri 1 Banjar Jawa, Kecamatan Buleleng, Kabupaten Buleleng, Provinsi Bali tahun pelajaran 2017/2018.
\end{abstract}

Kata kunci: $\quad$ Group Investigation (GI), Media Audio Visual, Hasil Belajar IPS

\begin{abstract}
This study aims to determine the social sciences outcomes after applied cooperative learning model type Group Investigation (GI) assisted audio visual media at grade V SD Negeri 1 Banjar Jawa in Academic Year 2017/2018. This research was a type of classroom action research conducted in two cycles and each cycle consists of 4 stages: planning, action, observation/evaluation, and reflection. Each cycle was held in 3 meetings consisting of 2 meetings to implement learning, 1 meeting to evaluation. The subjects of the study were the students of grade V of SD Negeri 1 Banjar Jawa in Academic Year $2017 / 2018$ of 39 persons, 19 men and 20 women. The object of this study was the result of learning social sciences. Observer in this research were teacher of fifth grade and fellow student practice at SD Negeri 1 Banjar Jawa. Data collection method in this research was used test and nontes method. The test method was used for the assessment of knowledge, while the nontes method was used for attitude and skill assessment. The instrument of data collection used in this research was objective sheet, attitude evaluation observation sheet, and student skill assessment observation sheet. The data have been collected, analyzed using descriptive statistical analysis method and quantitative descriptive analysis. Percentage of learning outcomes in cycle I is $73 \%$, while in cycle II is $87 \%$, and an increase in learning outcomes of 0.51 . Based on the result, it can be concluded that the application of cooperative learning
\end{abstract}


model of group investigation (GI) type can improve social sciences learning outcomes in fifth grade students of SD Negeri 1 Banjar Jawa, Buleleng District, Buleleng Regency, Bali Province in Academic Year 2017/2018.

Keywords: Group Investigation (Gl), Audio Visual Media, Social Sciences Learning Outcomes

\section{Pendahuluan}

Salah satu cerminan dari sebuah negara adalah Sumber Daya Manusia (SDM). Sebuah negara akan maju apabila memiliki kualitas SDM yang tinggi. Kualitas SDM yang tinggi dapat dicapai melalui jalur pendidikan. Oleh karena itu kualitas pendidikan sangatlah berpengaruh terhadap kualitas SDM sebuah negara. Pendidikan dalam sebuah negara dapat dikategorikan baik jika tujuan pendidikan dalam sebuah negara dapat tercapai.

Pada dasarnya pendidikan merupakan sebuah proses yang bertujuan untuk membantu manusia agar mampu menghadapai tantangan kedepannya. Apabila kualitas pendidikan di Indonesia masih rendah, maka jelaslah kemampuan untuk menghadapi tantangan kedepannya pun akan rendah pula. Berdasarkan data Indek Pengembangan Manusia (Human Development Index), apabila dibandingkan dengan negara-negara di kawasan Asia tenggara, Indonesia masih jauh tertinggal dari negara tetangga seperti Singapura dan Malaysia. Dari 188 negara yang telah disurvei, Indonesia menduduki peringkat ke-113 yang dikategorikan dalam kategori sedang. Hal tersebut sangat jauh berbeda dengan Singapura yang menduduki posisi ke-5, Brunei Darussalam yang menduduki posisi ke-30, dan Malaysia yang menduduki posisi 59. Dari data tersebut dapat dilihat bahwa kualitas SDM di Indonesia masih tergolong rendah. Sehingga hal tersebut belum sesuai dengan apa yang tercantum pada pembukaan UUD 1945 yaitu tujuan nasional pendidikan yaitu, “...mencerdaskan kehidupan bangsa, ...". Untuk memperbaiki kualitas bangsa dan mencapai tujuan Nasional Pendidikan tersebut, Pemerintah Republik Indonesia melalui Kementerian Pendidikan dan Kebudayaan berupaya mengadakan perbaikan dan pembaharuan sistem pendidikan di Indonesia, yaitu dalam bentuk pembaharuan kurikulum, penataan guru, peningkatan manajemen pendidikan, dan pembangunan sarana dan prasarana pendidikan. Kurikulum terbaru yang diterapkan saat ini adalah Kurikulum 2013. Berdasarkan permendikbud nomor 20 tahun 2016 tentang standar kompetensi lulusan pendidikan dasar dan menengah, dinyatakan bahwa lulusan sekolah dasar yang menerapkan kurikulum 2013 seyogyanya memiliki sikap yang mencerminkan orang yang beriman, berkarakter, jujur, peduli, bertanggung jawab, menjadi pembelajar yang sejati sepanjang hayat, sehat jasmani, dan rohani. Lulusan sekolah dasar juga hendaknya memiliki pengetahuan yang faktual, konseptual, prosedural, dan metakognitif. Selain sikap dan pengetahuan, lulusan sekolah dasar hendaknya memiliki keterampilan berpikir dan bertindak kreatif, produktif, kritis, mandiri, kolaboratif, dan komunikatif. Kurikulum 2013 dinyatakan berhasil jika lulusannya lebih produktif, kreatif, inovatif, afektif, dan lebih senang belajar, Daryanto (2014). Dengan demikian, siswa dituntut untuk lebih aktif dalam setiap pembelajaran. Ketika siswa aktif dalam pembelajaran, maka secara tidak langsung apa yang diinginkan dalam kurikulum 2013 akan terpenuh.

Untuk mewujudkan hal tersebut, salah satu faktor yang dapat memberikan kontribusi tinggi yaitu proses kegiatan belajar mengajar. Menurut Gagne (dalam Susanto, 2013), kegiatan belajar mengajar merupakan sebuah proses yang didalamnya terkandung interaksi antara guru dengan siswa, siswa dengan siswa yang bertujuan untuk memperoleh pengetahuan. Kegiatan belajar akan dapat dikatakan baik apabila kegiatan belajar tersebut dapat memberikan makna kepada siswa, siswa mampu setidaknya mengingat sebagian besar materi yang telah dipelajari di sekolah. Mengingat karakteristik siswa sekolah dasar yang masih dalam tahap operasional konkret, untuk membuat siswa mendapatkan pembelajaran yang bermakna dan tidak mudah dilupakan siswa, maka siswa harus ikut berperan dalam pembelajaran. Pembelajaran yang dilakukan hendaknya sebagian besar berpusat pada siswa. Seluruh pihak yang berkepentingan 
dalam bidang pendidikan pastinya memiliki harapan bahwa siswa haruslah mencapai hasil belajar yang sebaik mungkin. Berbagai upaya telah dilakukan untuk menangani hal tersebut.

Namun kenyataannya di lapangan, usaha-usaha yang telah dilakukan pemerintah tersebut ternyata masih belum tercapai sepenuhnya. Hal tersebut dapat dilihat dari hasil observasi dan wawancara yang telah dilakukan dengan guru kelas $\mathrm{V}$ dan 4 orang siswa SD Negeri 1 Banjar Jawa, Kecamatan Buleleng, Kabupaten Buleleng, Provinsi Bali. Berdasarkan hasil wawancara dengan guru kelas V (Bu Kadek Sukini) pada Selasa, 6 Februari 2018 pukul 10.00 WITA, menjelaskan bahwasannya ketika mengajar tema yang didalamnya terkandung muatan pelajaran IImu Pengetahuan Sosial (IPS) khususnya materi yang sifatnya hafalan, beliau sendiri sedikit kesusahan dalam mengajarkan ke siswa. Hal tersebut dikarenakan materi yang padat dan siswa sendiri susah untuk mengingat materi yang berupa hafalan. Selain guru kelas V, siswa sendiri pun mengaku kesusahan dalam menerima materi muatan pelajaran IPS, khususnya materi yang berisikan hafalan. Setelah dilakukan observasi pembelajaran di dalam kelas, didapatkan hasil bahwa: 1) pembelajaran IPS di kelas $\mathrm{V}$ belum menerapkan model pembelajaran yang mengaktifkan siswa, guru cenderung lebih menggunakan metode ceramah dan tanya jawab, 2) guru hanya sedikit menggunakan media pembelajaran, 3) lebih dari $50 \%$ siswa kurang aktif ketika muatan yang diajarkan adalah muatan pelajaran IPS. Akibat dari hal tersebut yaitu kurangnya minat siswa terhadap mata pelajaran IPS, sehingga hasil belajarnyapun cenderung dalam kategori sedang. Hal tersebut dapat dilihat dari hasil belajar siswa yaitu rata-rata mendapat nilai 68 yang tergolong pada kategori sedang. Hasil belajar siswa yang baik apabila hasil belajarnya berada pada rentangan nilai baik sampai sangat baik.

IPS merupakan salah satu muatan pelajaran dalam pembelajaran tematik di sekolah untuk penerapan kurikulun 2013. Menurut Susanto (2013), pelajaran IPS adalah ilmu pengetahuan yang mempelajari berbagai disiplin ilmu yang nantinya berguna di dalam kehidupan masyarakat. Itu sebabnya pelajaran IPS sangat penting diajarkan di sekolah. Siswa akan dapat bersosialisasi dengan baik, bermasyarakat dengan baik karena pelajaran IPS yang dipelajari siswa baik itu langsung ataupun tidak langsung. Pelajaran IPS sering dianggap mmembosankan bagi siswa karena terlalu banyak materi yang harus dibaca siswa. Untuk mengatasi permasalahan tersebut, hendaknya dalam mengajarkan muatan IPS tidak cukup hanya menggunakan metode konvensional saja, namun model-model yang dapat mengaktifkan siswa. Oleh karena itu, siswa juga harus dituntut untuk aktif dalam proses pembelajaran IPS di kelas agar pembelajaran IPS di kelas dapat bermakna bagi siswa. Pelajaran IPS tidak hanya cukup diajarkan dengan cara menjelaskan saja. Hal tersebut akan membuat kesan bahwa pelajaran IPS merupakan pelajaran yang membosankan. Guru semestinya menggunakan berbagai metode dan media dalam mengajarkan pelajaran IPS (Susanto, 2013). Dengan kesan terhadap pelajaran IPS yang memang sudah membosankan, siswa akan terbiasa untuk menghafal materi-materi yang dijelaskan oleh guru. Sehingga apabila suatu ketika diberikan pertanyaan mengenai materi yang telah dipelajari, siswa cenderung lupa dengan apa yang dihapalkan. Itulah salah satu sebabnya siswa beranggapan bahwa pelajaran IPS cukup membosankan untuk dipelajari. Hal tersebut berdampak pada rendahnya hasil belajar IPS yang diperoleh siswa.

Rendahnya hasil belajar IPS siswa tidak terlepas dari pemilihan model dan media yang digunakan oleh guru dalam mengajar. Seorang siswa dapat mengikuti pembelajaran dengan baik dan mencapai hasil belajar yang baik pula, apabila siswa didukung oleh kondisi lingkungan belajar yang bagus dan dengan pemilihan model serta media yang sesuai dengan keperluan dan karakteristik siswa. Alternatif yang dapat ditawarkan untuk mencapai hal tersebut adalah model pembelajaran kooperatif tipe group investigation (GI) berbantuan media audio visual. Menurut Irma Kurniasih \& Berlin Sani (dalam Yulitha, 2017:10), "Model pembelajaran Group Investigation (GI) adalah salah satu bentuk model pembelajaran kooperatif yang memiliki titik tekan pada partisipasi dan aktivitas siswa untuk mencari sendiri materi atau segala sesuatu mengenai mata pelajaran yang akan dipelajari" . Siswa bersama kelompok dituntut untuk aktif dalam menemukan dan membahas materi yang telah ditentukan sebelumnya. Apabila siswa lebih aktif dalam pembelajaran, siswa akan lebih kreatif dalam melakukan suatu hal. Selain itu, 
siswa juga akan aktif menemukan sendiri pengetahuan-pengetahuan yang hendak dipelajarinya tanpa harus diberikan oleh guru. Dalam hal ini guru bertugas sebagai fasilitator dan bertugas untuk memperbaiki kesalahan-kesalahan yang mungkin sempat disimpulkan oleh siswa. Sebuah model pembelajaran akan menjadi lebih bermakna ketika diterapkan apabila dilengkapi dengan media pembelajaran. Media pembelajaran berfungsi untuk menjembatani siswa agar lebih mudah mempelajari materi yang diajarkan. Oleh karenanya agar dapat mempelajari muatan IPS yang dianggap terlalu membosankan, akan efektif kiranya jika diajarkan menggunakan model pembelajaran kooperatif tipe group investigation dengan bantuan media audio-visual. Karena selain dapat melihat, siswa juga dapat mendengarkan penjelasan materi melalui media audio visual. Menurut Djamarah (2002), media audio visual merupakan sebuah media yang memiliki dua unsur yakni unsur suara dan gambar. Unsur suara dan gambar memafaatkan dua indera yang dimiliki manusia yaitu indera pendengaran dan indera penglihatan. Dengan memanfaatkan dua indera ini secara maksimal dalam pembelajaran, maka hasil yang diperoleh seyogyanya juga akan dapat diperoleh secara maksimal.

Tujuan dari adanya penelitian ini yaitu untuk mengetahui hasil belajar IPS setelah diterapkan model pembelajaran kooperatif tipe group investigation (GI) berbantuan media audio visual pada siswa kelas V SD Negeri 1 Banjar Jawa Tahun pelajaran 2017/2018.

\section{Metode}

Jenis penelitian yang digunakan yaitu penelitian tindakan kelas yang dilaksanakan dalam dua siklus. Pada setiap siklus dilaksanakan dalam empat tahapan yang meliputi tahap perencananaan, tahap tindakan, tahap observasi/evaluasi, dan tahap refleksi. Setiap siklus dilaksanakan dalam tiga kali pertemuan yang terdiri dari dua kali pertemuan untuk membelajarkan materi dan satu kali pertemuan untuk mengadakan evaluasi. Penelitian ini dilaksanakan di SD Negeri 1 Banjar Jawa, Kecamatan Buleleng, Kabupaten Buleleng, Provinsi Bali pada semester genap tahun pelajaran 2017/2018. Subjek pada penelitian ini yaitu siswa kelas V SD Negeri 1 Banjar Jawa Tahun Pelajaran 2017/2018 sebanyak 39 orang yang terdiri atas 19 orang siswa putra dan 20 orang siswa putri. Sedangkan untuk objek penelitiannya yaitu hasil belajar IPS siswa kelas V SD Negeri 1 Banjar Jawa terhadap penerapan model pembelajaran kooperatif tipe Group Investigation (Gl). Observer dalam penelitian ini yaitu guru kelas $\mathrm{V}$ dan rekan mahasiswa PPL SD Negeri 1 Banjar Jawa. Penelitian ini terdiri dari dua buah variabel yaitu variabel bebas dan variabel tergantung. Variabel bebas pada penelitian ini yaitu model pembelajaran kooperatif tipe group investigation berbantuan media audio visual. Sedangkan variabel tergantung pada penelitian ini yaitu hasil belajar IPS siswa kelas V SD Negeri 1 Banjar Jawa.

Metode pengumpulan data pada penelitian ini yaitu menggunakan metode tes dan nontes. Instrumen pengumpulan data yang digunakan pada penelitian ini yaitu lembar soal obyektif, lembar observasi penilaian sikap, dan lembar observasi penilaian keterampilan siswa. Data yang telah berhasil dikumpulkan, kemudian dianalisis. Untuk menganalisis data tersebut digunakan metode analisis statistik deskriptif dan metode analisis deskriptif kuantitatif. Koyan (2012) mengungkapkan bahwa statistik deskriptif berfungsi untuk membuat data menjadi bermakna. Data yang bermakna dapat disajikan dalam bentuk distribusi frekuensi, grafik, angka rata-rata, median, modus, dan standar deviasi untuk menggambarkan keadaan objek/variabel sehingga diperoleh kesimpulan umum. Metode analisis deskriptif kuantitatif merupakan salah satu metode yang digunakan dalam mengolah data suatu penelitian. Agung (dalam Agung, 2014:144) menyatakan bahwa metode analisis deskriptif kuantitatif adalah suatu cara pengolahan data yang dilakukan dengan jalan menyusun secara sistematis dalam bentuk angka-angka dan atau persentase mengenai keadaan suatu objek yang diteliti sehingga diperoleh kesimpulan umum. Persentase hasil belajar yang didapat kemudian dikonversikan ke dalam Penilaian Acuan Patokan (PAP) skala lima. Persentase ketuntasan belajar siswa yang dipakai dalam penelitian ini adalah minimal $80 \%$ siswa mencapai KKM yang ditetapkan oleh sekolah dan berada dalam kategori baik atau sangat baik. Peningkatan hasil belajar dihitung 
menggunakan rumus gains skor ternormalisasi. Kriteria keberhasilan dalam penelitian ini yaitu persentase rata-rata (M\%) hasil belajar IPS siswa kelas V SD Negeri 1 Banjar Jawa tahun pelajaran 2017/2018 telah mencapai kategori "Tinggi", yang mana berada pada interval 80-89. Apabila indikator keberhasilan ini telah tercapai, penelitian dapat dihentikan. Namun, apabila persentase rata-rata (M\%) belum mencapai kategori "Tinggi", penelitian akan dilanjutkan ke siklus selanjutnya.

\section{Hasil dan Pembahasan}

Pada siklus I, peneliti melaksanakan tatap muka dengan siswa sebanyak 3 kali diantaranya 2 pertemuan untuk melaksanakan pembelajaran sesuai dengan model yang diterapkan dan 1 pertemuan untuk tes evaluasi hasil belajar. Penelitian ini dilaksanakan melalui 4 tahapan yaitu perencanaan, tindakan, observasi/evaluasi, dan refleksi.

Siswa yang hadir sebanyak 39 orang. Jumlah tersebut merupakan jumlah keseluruhan dari banyaknya siswa kelas VA. Aktivitas siswa diamati selama kegiatan pembelajaran berlangsung. Aktivitas siswa pada siklus 1 ini diamati oleh guru kelas $V$ (Ni Kadek Sukini, S.Pd.SD) dan I Dewa Ayu Ratnadewi, S.Pd. Hasil observasi yang diperoleh menunjukkan aktivitas siswa dapat dikategorikan baik. Berdasarkan diskusi dengan para observer, didapatkan beberapa permasalahan yang terjadi pada pembelajaran di siklus 1 yaitu: (1) aktivitas siswa masih kurang terkontrol; (2) Saat salah satu kelompok mempresentasikan hasil diskusi kelompoknya, beberapa siswa belum memperhatikan secara maksimal; (3) Siswa masih belum termotivasi untuk belajar. Selain permasalahan di atas, ditemukan pula sisi posiitifnya yaitu siswa memperhatikan ketika guru menjelaskan di depan kelas, bertanya jika ada kesulitan, dan mengerjakan tugas dengan baik.

Aktivitas guru diamati selama proses pembelajaran berlangsung dari awal sampai akhir kegiatan pembelajaran. Aktivitas guru ini diamati oleh guru kelas V (Ni Kadek Sukini, S.Pd.SD) dan I Dewa Ayu Ratnadewi, S.Pd. Hasil yang didapat menunjukkan aktivitas guru dalam menerapkan model pembelajaran dapat dikategorikan baik. Berdasarkan diskusi dengan para observer, terdapat beberapa permasalahan selama proses pembelajaran yang dilakukan guru, yaitu: (1) beberapa kegiatan ini masih belum dilaksanakan oleh guru sehingga siswa kurang termotivasi dalam belajar; (2) kurang mengontrol aktivitas siswa ketika belajar dan presentasi hasil kerja.

Hasil belajar IPS siswa kelas $V$ diukur menggunakan metode tes. Tes evaluasi tersebut berupa pilihan dengan jumlah soal sebanyak 20 butir dan diambil di akhir setiap siklus. Setiap butir soal yang dijawab benar memperoleh skor 1 sehingga skor maksimal ideal dalam hasil belajar ini adalah 20. Data hasil belajar IPS yang diperoleh pada siklus I disajikan pada Tabel 1.

Tabel 1. Rekapitulasi Perhitungan Tendensi Data Hasil Belajar IPS Siswa Siklus I

\begin{tabular}{cc}
\hline Tendensi Data & Hasil Perhitungan \\
\hline Modus & 16 \\
Median & 15 \\
Mean & 15 \\
Rentangan & 11 \\
\hline
\end{tabular}

Berdasarkan nilai modus, median, dan mean yang telah didapatkan, maka data hasil belajar IPS pada siklus I disajikan pada Gambar 1. 


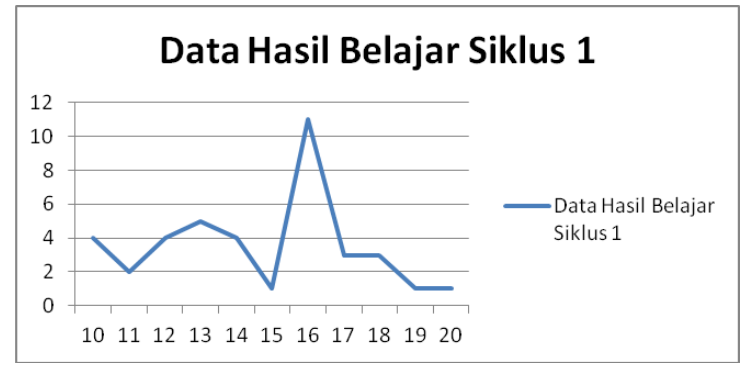

Gambar 1. Grafik Hasil Belajar Siklus 1

Berdasarkan grafik di atas, dilihat bahwa median data dan mean data berada pada skor yang sama, yaitu 15, sedangkan modus data yaitu 16. Oleh karena itu, dapat diperoleh harga statistik Mo > M $(16>15)$. Sehingga, dapat diinterpretasikan bahwa skor yang memiliki frekuensi tertinggi adalah skor yang berada di atas rata-rata.

Hasil perhitungan persentase hasil belajar pada siklus I yang diperoleh adalah sebesar $73 \%$. Persentase hasil belajar tersebut dikonversikan ke dalam penilaian acuan patokan (PAP) skala lima dan dikategorikan sedang. Hasil perhitungan ketuntasan belajar didapatkan ketuntasan belajar pada siklus ! adalah $69 \%$. Berdasarkan pencapaian tersebut, hasil pada siklus I belum mencapai indikator keberhasilan yang telah ditetapkan (M\% berada pada kategori "Tinggi", ketuntasan belajar $80 \%$ ), sehingga penelitian perlu dilanjutkan ke siklus II.

Secara umum prosedur yang dilaksanakan hampir sama dengan siklus I yaitu melaksanakan tatap muka dengan siswa sebanyak 3 kali diantaranya 2 pertemuan untuk melaksanakan pembelajaran sesuai dengan model yang diterapkan dan 1 pertemuan untuk tes evaluasi hasil belajar IPS. Penelitian ini juga dilaksanakan melalui 4 tahapan yaitu perencanaan, tindakan, observasi/ evaluasi, dan refleksi.

Pada siklus II ini, siswa yang hadir sebanyak 39 orang. Jumlah tersebut merupakan jumlah keseluruhan dari banyaknya siswa kelas VA. Aktivitas siswa diamati selama kegiatan pembelajaran berlangsung. Aktivitas siswa pada siklus II ini diamati oleh guru kelas $\mathrm{V}(\mathrm{Ni}$ Kadek Sukini, S.Pd.SD) dan A.A. Istri Dianika Perama Dewi, S.Pd. Hasil observasi yang diperoleh menunjukkan perkembangan. Aktivitas siswa dalam pembelajaran dikategorikan pada kategori sangat baik. Pembelajaran pada siklus ini telah mengalami perbaikan dari siklus yang pertama. Berdasarkan diskusi dengan para observer, aktivitas siswa telah dapat dikontrol, aktivitas siswa hampir seluruhnya mengarah pada kegiatan pembelajaran yang dilakukan guru, siswa juga telah termotivasi untuk belajar karena adanya permainan di awal pembelajaran. Selain itu, pada saat kegiatan presentasi, siswa telah memperhatikan dengan baik. Hal tersebut diatasi dengan memberikan sanksi kepada siswa yang tidak memperhatikan saat kegiatan presentasi berlangsung. Kekurangan-kekurangan yang terjadi pada siklus I telah diperbaiki oleh guru.

Aktivitas guru pada siklus II ini diamati selama proses pembelajaran berlangsung dari awal sampai akhir kegiatan pembelajaran. Aktivitas guru ini diamati oleh guru kelas $\mathrm{V}(\mathrm{Ni}$ Kadek Sukini, S.Pd.SD) dan A.A. Istri Dianika Perama Dewi, S.Pd. Hasil yang didapat menunjukkan aktivitas guru dikategorikan pada kategori sangat baik. Berdasarkan hasil tersebut, dapat dilihat bahwa peneliti telah dapat melaksanakan pembelajaran dengan sangat baik. Peneliti telah memperbaiki hal-hal yang menjadi kekurangan pada siklus I. Berdasarkan diskusi dengan para observer, Kegiatan yang dilakukan peneliti sudah sesuai dengan rencana pembelajaran dan peneliti sudah memberikan motivasi yang sangat baik kepada siswa sehingga siswa dapat termotivasi untuk belajar.

Sama halnya seperti siklus I, pada siklus II hasil belajar IPS siswa juga diukur menggunakan metode tes. Data hasil belajar pada siklus II disajikan pada Tabel 2. 
Tabel 2. Rekapitulasi Perhitungan Tendensi Data Hasil Belajar IPS Siswa Siklus II

\begin{tabular}{cc}
\hline Tendensi Data & Hasil Perhitungan \\
\hline Modus & 17 \\
Median & 17 \\
Mean & 17 \\
Rentangan & 7 \\
\hline
\end{tabular}

Berdasarkan nilai modus, median, dan mean yang telah didapatkan, maka data hasil belajar IPS pada siklus II disajikan pada Gambar 2.

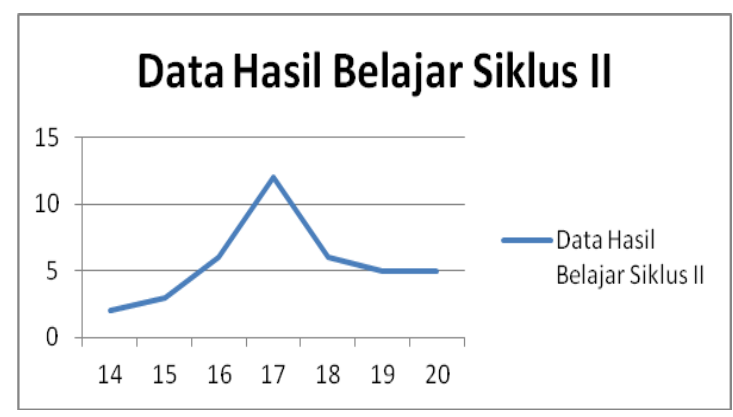

Gambar 2. Grafik Hasil Belajar Siklus II

Berdasarkan grafik di atas, dilihat bahwa median data dan mean data berada pada skor yang sama, yaitu 15 , sedangkan modus data yaitu 16. Oleh karena itu, dapat diperoleh harga statistik $\mathrm{Mo}=\mathrm{M}(17=17)$. Sehingga, dapat diinterpretasikan bahwa skor yang memiliki frekuensi tertinggi adalah skor yang berada di pada rata-rata kelas.

Hasil perhitungan persentase hasil belajar pada siklus II yang diperoleh adalah sebesar 87\%. Persentase hasil belajar tersebut dikonversikan ke dalam penilaian acuan patokan (PAP) skala lima dan dikategorikan Tinggi. Hasil perhitungan ketuntasan belajar didapatkan ketuntasan belajar pada siklus II adalah 100\%. Berdasarkan pencapaian tersebut, hasil pada siklus II sudah mencapai indikator keberhasilan yang telah ditetapkan (M\% berada pada kategori "Tinggi", ketuntasan belajar 80\%), sehingga penelitian dapat dihentikan.

Peningkatan hasil belajar dari siklus I ke siklus II dihitung menggunakan rumus gains skor ternormalisasi. Berdasarkan perhitungan yang dilakukan, didapatkan hasil bahwa terjadi peningkatan sebesar 0,51. Peningkatan tersebut dikonversikan ke dalam kriteria peningkatan gains skor dan dikategorikan ke dalam kategori sedang. Sehingga kualitas dari penelitian ini dapat dikatakan cukup baik.

Rekapitulasi peningkatan hasil belajar IPS disajikan pada Tabel 3.

Tabel 3. Rekapitulasi Peningkatan Hasil Belajar IPS

\begin{tabular}{lrrc}
\hline \multicolumn{1}{c}{ Siklus } & Siklus I & Siklus II & Peningkatan \\
\hline Indikator & $73 \%$ & $87 \%$ & $14 \%$ \\
\hline Persentase Rata-rata (M\%) & $69 \%$ & $100 \%$ & $31 \%$ \\
\hline
\end{tabular}

Hasil penelitian yang dilaksanakan pada siswa kelas V SD Negeri 1 Banjar Jawa menunjukkan bahwa penerapan model pembelajaran kooperatif tipe group investigation (GI) berbantuan media audio visual dapat meningkatkan hasil belajar IPS siswa kelas V SD Negeri 1 Banjar Jawa tahun pelajaran 2017/2018. Hal tersebut dapat dilihat dari perolehan persentase rata-rata $(\mathrm{M} \%)$ dan ketuntasan belajar (KB) siswa kelas V. Persentase rata-rata $(\mathrm{M} \%)$ hasil belajar IPS siswa meningkat sebanyak 14\%. Peningkatan tersebut dapat dilihat dari persentase 
rata-rata pada siklus I $73 \%$ meningkat menjadi $87 \%$ pada siklus II. Berdasarkan pedoman penilaian acuan patokan (PAP) skala lima, terlihat bahwa pada siklus I, hasil belajar siswa tergolong dalam kategori sedang dan pada siklus II hasil belajar siswa tergolong pada kategori tinggi. Selain itu, keberhasilan penelitian ini juga dapat dilihat dari ketuntasan belajar (KB) siswa. Ketuntasan belajar siswa meningkat sebanyak 31\%. Pada siklus I ketuntasan belajar siswa mencapai $69 \%$ meningkat menjadi $100 \%$ di siklus II. Ketuntasan belajar $100 \%$ artinya seluruh siswa kelas $\mathrm{V}$ telah mencapai ketuntasan belajar yang diharapkan sepenuhnya. Berdasarkan perhitungan menggunakan gains skor ternormalisasi, didapatkan hasil peningkatan sebesar 0,51 . Hasil tersebut dikategorikan pada kategori sedang. Hal itu berarti kualitas penelitian ini cukup baik untuk meningkatkan hasil belajar siswa.

Peningkatan hasil belajar IPS siswa dari siklus I ke siklus II dipengaruhi oleh beberapa faktor. Adapun faktor-faktor yang mempengaruhi peningkatan hasil belajar IPS siswa yaitu: (1) Model pembelajaran kooperatif tipe group investigation (Gl) merupakan model pembelajaran yang menekankan pada kelompok yang membahas sebuah materi secara mengkhusus. Pada model ini siswa akan saling bertukar pikiran dengan anggota kelompoknya, sehingga siswa pun akan lebih bisa untuk bekerja sama dengan orang lain. Dengan kerjasama, siswa akan lebih mudah memecahkan permasalahan yang dihadapi. Oleh karena itu, dengan penerapan model ini pelajaran IPS yang sebelumnya dirasa susah akan lebih mudah dipahami dan diingat oleh siswa; (2) Pada model pembelajaran kooperatif tipe group investigation (GI), pembelajaran dilaksanakan secara berkelompok dengan masing-masing kelompok memilih sendiri materi yang dibahas di kelompok. Seluruh materi dibagi rata dengan masing-masing kelompok. Dengan pemilihan materi dan pembagian materi yang akan dibahas, materi yang luas akan terjangkau secara keseluruhan. Selain itu, dengan membagi rata materi, siswa lebih fokus untuk membahas materi secara spesifik; (3) Selain peran dari model pembelajaran kooperatif tipe group investigation (Gl), keberhasilan penelitian ini juga ditentukan dari media yang digunakan. Media yang digunakan pada penelitian ini yaitu media audio visual. Media audio visual merupakan media yang memanfaatkan 2 macam indera, indera penglihatan dan indera pendengaran. Dengan menggunakan 2 indera tersebut, siswa akan lebih maksimal dalam belajar. Pembelajaran yang berlangsung pun akan lebih bermakna karena siswa dapat melihat dan mendengar hampir secara nyata kejadian yang berhubungan dengan pembelajaran yang berlangsung. Salah satu karakteristik pelajaran IPS adalah berhubungan dengan lingkungan sosial, sehingga ketika siswa ditampilkan video-video yang berhubungan dengan materi kegiatan ekonomi, maka siswa akan lebih mudah dan lebih bisa merasakan bagaimana situasi kegiatan ekonomi secara nyata sehingga pembelajaran akan lebih bermakna; (4) Pada penelitian ini, sebelum melaksanakan pembelajaran peneliti memberikan permainan dan tepuk kepada siswa. Selain di awal, di sela-sela pembelajaran pun peneliti memberikan tepuk kepada siswa. Hal itu bertujuan untuk memberikan selingan kepada siswa, sehingga siswa tidak bosan mengikuti pembelajaran. Dengan adanya permainan dan tepuk itu siswa lebih termotivasi untuk mengikuti pelajaran; dan (5) Selain memberikan permainan dan tepuk, peneliti juga selalu memberikan penghargaan kepada siswa yang dapat menjawab dan melaksanakan tugas dengan baik. Hal tersebut juga sangat mendukung keberhasilan penelitian ini karena dengan memberikan penghargaan siswa menjadi lebih termotivasi untuk belajar.

Keberhasilan penelitian ini juga didukung oleh beberapa penelitian yang telah dilakukan sebelumnya oleh peneliti yang lain. Beberapa penelitian yang mendukung penelitian ini yaitu dilakukan oleh Erlisnawati (2014) dengan judul penelitian "Penerapan Model Pembelajaran Kooperatif Tipe Group Investigation Untuk Meningkatkan Hasil Belajar IPS Siswa Kelas IV SD Negeri 56 Pekanbaru". Hasil penelitian tersebut menunjukkan bahwa model pembelajaran kooperatif tipe group investigation dapat meningkatkan hasil belajar mata pelajaran IPS pada siswa kelas IV. Selain itu, beberapa penelitian yang lain juga menunjukkan hal yang serupa bahwa model pembelajaran kooperatif tipe group investigation (Gl) dapat meningkatkan hasil belajar siswa.

Berdasarkan paparan di atas, maka dapat disimpulkan bahwa penerapan model pembelajaran tipe group investigation (GI) berbantuan media audio visual dapat meningkatkan 
hasil belajar IPS pada siswa kelas V SD Negeri 1 Banjar Jawa, Kecamatan Bulelelng, Kabupaten Buleleng, Provinsi Bali tahun pelajaran 2017/2018.

\section{Simpulan dan Saran}

Berdasarkan hasil penelitian yang didapatkan, terdapat peningkatan persentase rata-rata hasil belajar IPS siswa kelas V. Peningkatan persentase rata-rata hasil belajar IPS siswa meningkat sebesar $14 \%$. Persentase rata-rata hasil belajar IPS pada siklus I sebesar $73 \%$ (sedang) meningkat menjadi $87 \%$ (tinggi). Selain itu, ketuntasan belajar siswa meningkat sebesar 31\%. Ketuntasan belajar pada siklus I sebesar 69\% meningkat menjadi $100 \%$. Peningkatan hasil belajar berdasarkan perhitungan gains skor yaitu sebesar 0,51 (sedang). Maka dari itu dapat disimpulkan bahwa penerapan model pembelajaran kooperatif tipe group investigation (GI) dapat meningkatkan hasil belajar IPS pada siswa kelas V SD Negeri 1 Banjar Jawa, Kecamatan Buleleng, Kabupaten Buleleng, Provinsi Bali tahun pelajaran 2017/2018.

Saran yang dapat diajukan peneliti berdasarkan penelitian yang telah dilakukan yaitu: (1) disarankan kepada seluruh siswa kelas V SD Negeri 1 Banjar Jawa, agar dapat meningkatkan hasil belajar dan meningkatkan semangat belajar dalam mengikuti proses pembelajaran; (2) disarankan kepada guru yang mengajar di kelas V SD Negeri 1 Banjar Jawa, agar mampu melanjutkan penerapan model pembelajaran kooperatif tipe group investigation (Gl) sebagai suatu alternatif dalam meningkatkan hasil belajar siswa; (3) disarankan kepada kepala sekolah, agar dapat meningkatkan penyelenggaraan pendidikan di sekolah dengan penerapan model pembelajaran kooperatif tipe group investigation (GI) sebagai suatu alternatif dalam meningkatkan hasil belajar siswa; dan (4) disarankan kepada peneliti lain, agar dapat menggunakan penelitian ini sebagai referensi tambahan ketika melaksanakan penelitian terkait penggunaan model pembelajaran kooperatif tipe group investigation (GI).

\section{Daftar Rujukan}

Agung, A.A. Gede. 2014. Metodologi Penelitian Pendidikan. Singaraja: Aditya Media Publishing.

Daryanto. 2014. Pendekatan Pembelajaran Saintifik Kurikulum 2013. Yogyakarta: Gava Media.

Djamarah, Syaiful Bahri. 2002. Strategi Belajar Mengajar. Jakarta: Rineka Cipta.

Erlinaswati. 2014. "Penerapan Model Pembelajaran Kooperatif Tipe Group Investigation Untuk Meningkatkan Hasil Belajar IPS Siswa Kelas IV SD Negeri 56 Pekanbaru". Jurnal Primary Program Studi Pendidikan Guru Sekolah Dasar Fakultas Keguruan dan IImu Pendidikan Universitas Riau, Volume 3, Nomor 1 (hlm. 9-14).

Koyan, I W. 2012. Statistik Pendidikan. Singaraja: Undiksha Press.

Peraturan Menteri Pendidikan dan Kebudayaan Republik Indonesia Nomor 20 Tahun 2016.

Susanto, Ahmad. 2013. Teori Belajar dan Pembelajaran di Sekolah Dasar. Jakarta: Prenada Media.

Undang-Undang Republik Indonesia Nomor 20 Tahun 2003 tentang Sistem Pendidikan Nasional.

UNDP. 2016. Human Development Report 2016. New York: Oxford University Press.

Yulitha, Ika. 2017. Pengaruh Model Pembelajaran Group Investigation (GI) terhadap Motivasi Belajar IPS Siswa Kelas VII SMP Negeri 1 Pulaupanggung Kabupaten Tanggamus Tahun 
Ajaran 2015/2016. Skripsi. Program Studi Pendidikan Sejarah, Jurusan Pendidikan IImu Pengetahuan Sosial, Fakultas Keguruan dan IImu Pendidikan, Universitas Lampung. 